\title{
Enclavamiento torácico mortal durante un accidente de tráfico.
}

Fatal thoracic impalement during a traffic accident.

Varón de 34 años que conducía un camión dedicado al transporte de muebles que fallece durante un accidente de tráfico. Su vehículo se salió de la calzada por su margen derecho y colisionó frontalmente contra una pequeña casa deshabitada. El camión sufrió aparatosos daños en la parte frontal y lateral derecha con deformación de la cabina y desprendimiento del parabrisas, a través del cual se introdujeron en el interior del vehículo varias tablas que componían la techumbre de la vivienda. Una tabla se rompió en dos fragmentos, uno de los cuales (de $105 \times 7 \times 4 \mathrm{~cm}$, con su extremo astillado) atravesó el tórax de uno de los pasajeros ocasionándole la muerte de forma casi instantánea (Figura I). En la autopsia, en el examen externo destacaba en la parte lateral derecha del tórax una profunda herida de bordes irregulares, con algunas excoriaciones lineales en sus márgenes (Figura 2). La cavidad pleural derecha contenía 1.050 cc de sangre. La cavidad pleural izquierda contenía 560 cc de sangre. El esófago estaba totalmente seccionado en la unión del tercio medio con el tercio inferior, observándose ambos extremos desflecados. La vena ácigos y el gran conducto torácico también estaban seccionados. El pulmón derecho mostraba una gran laceración que afectaba al lóbulo medio e inferior, el bronquio principal y la arteria pulmonar derecha. El hemidiafragma izquierdo presentaba un orificio a través del cual ascendía el estómago hasta la cavidad torácica. La pared torácica presentaba fractura del $4^{\circ}, 5^{\circ}, 6^{\circ}, 7^{\circ}$ y $8^{\circ}$ arcos costales derechos, con infiltrado hemorrágico perilesional.

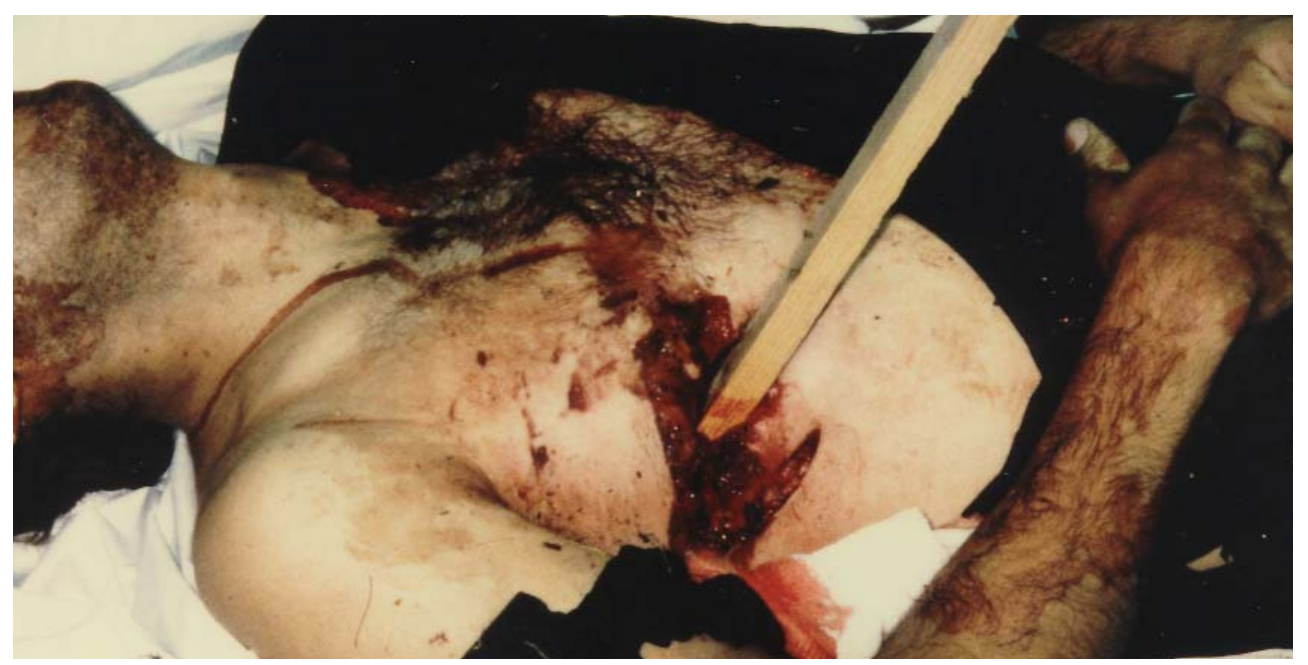

Figura 1.- Posición de la tabla que ocasionó el enclavamiento del conductor. 


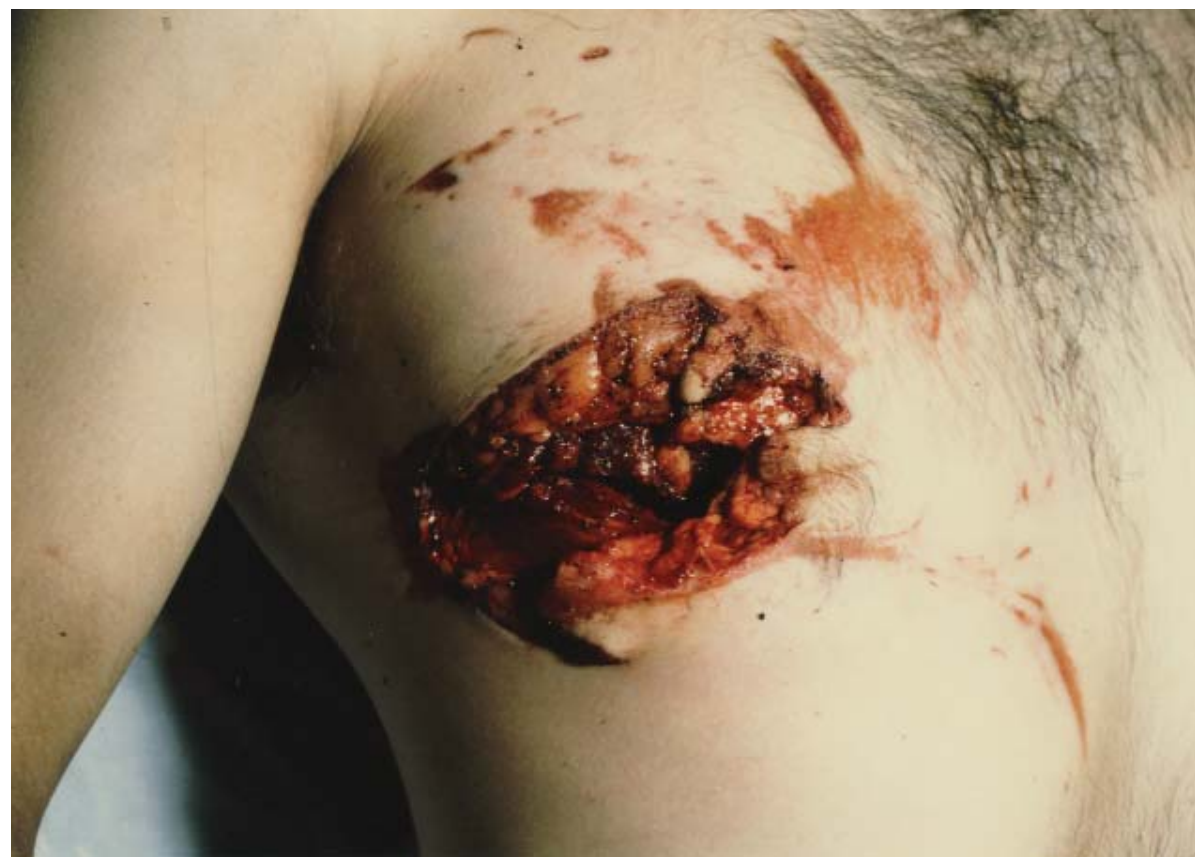

Figura 2.- Detalle de la herida torácica. 